University of Nebraska - Lincoln

DigitalCommons@University of Nebraska - Lincoln

Entomology Papers from Other Sources

Entomology Collections, Miscellaneous

1964

Resistance to the Chemical Sterilant, Apholate, in Aedes aegypti

E. I. Hazard

ARS-USDA

C. S. Lofgren

ARS-USDA

D. B. Woodard

ARS-USDA

H. R. Ford

ARS-USDA

B. M. Glancey

ARS-USDA

Follow this and additional works at: https://digitalcommons.unl.edu/entomologyother

Part of the Entomology Commons

Hazard, E. I.; Lofgren, C. S.; Woodard, D. B.; Ford, H. R.; and Glancey, B. M., "Resistance to the Chemical Sterilant, Apholate, in Aedes aegypti" (1964). Entomology Papers from Other Sources. 51.

https://digitalcommons.unl.edu/entomologyother/51

This Article is brought to you for free and open access by the Entomology Collections, Miscellaneous at DigitalCommons@University of Nebraska - Lincoln. It has been accepted for inclusion in Entomology Papers from Other Sources by an authorized administrator of DigitalCommons@University of Nebraska - Lincoln. 


\section{Resistance to the Chemical Sterilant, Apholate, in Aedes aegypti}

Abstract. Increased resistance to the sterilizing effects of apholate was observed in two colonies of Aedes aegypti (L.) exposed in the larval stage of each generation to concentrations of apholate that induced about 90 to 40 percent sterility in the eggs laid by the ensuing adults.

Since the inception of research on the potential of chemosterilants as insect control agents, many persons have asked whether insects could develop resistance to the sterilizing effects of these compounds. On the other hand, because the action of certain chemosterilants influences the induction of dominant lethal mutations, it has been theorized that continued exposure to substerilizing dosages or to dosages causing only partial sterility might result in accumulation of genetic defects and ultimate death of a colony.

In 1962 efforts were initiated to determine whether the yellow fever mosquito, Aedes aegypti (L.), could develop resistance to apholate (1). Weidhaas et al. (2) had reported that sterility could be induced in $A$. aegypti by feeding adult mosquitoes on honey solution containing 0.1 percent of apholate. Weidhaas (3) had also demonstrated that exposure of larvae of $A$. aegypti, from the third instar to pupation, in water containing 10 parts of apholate per million produced about 90 percent sterility in the ensuing males and about 50 percent sterility in females. When both sexes were treated, sterility was about 98 percent. In later experiments at this laboratory sterility induced by this larval treatment sometimes reached 100 percent. For our experiments in development of resist- 
ance, selection pressure was exerted by treatment in the larval stage.

Two different colonies of $A$. aegypti were subjected to selection. Treatment of the first colony began in December 1962 , and a second colony was subjected to selection pressure beginning in July 1963.

The strain of $A$. aegypti used in both experiments was from our regular colony, maintained at this laboratory for more than 20 years without deliberate exposure to insecticides. In each generation several hundred third-instar larvae were placed in shallow exposure pans that contained 1 liter of a solution of apholate $(5 \mathrm{ppm})$ in tapwater. In the first experiment the number of larvae in each pan varied, depending on the quantity available; in the second experiment 300 larvae were always used in each pan. After 24 hours, food consisting of powdered dog biscuit was added, and larvae were allowed to continue development in the treated water until they reached the pupal stage. Pupae were removed to untreated water, and emerging adults were allowed to remain together in a screen cage for about 5 days to permit mating. Females were then given a blood meal on a guinea pig. A day later a container which had been lined with filter paper, and containing water to keep the filter paper damp, was placed in the cage for oviposition. Eggs deposited by all the laying females

Table 1. Sterility of eggs from a colony of Aedes aegypti exposed in the larval stage of each generation to selection pressure with apholate and from treated and untreated mosquitoes from the regular colony.

\begin{tabular}{ccccc}
\hline $\begin{array}{c}\text { Gener- } \\
\text { ation } \\
\text { of } \\
\text { apho- } \\
\text { late } \\
\text { colony }\end{array}$ & $\begin{array}{c}\text { Concen- } \\
\text { tration } \\
\text { apholate }\end{array}$ & $\begin{array}{c}\text { Sterility of mos- } \\
\text { quitoes exposed } \\
\text { to apholate }\end{array}$ & $\begin{array}{c}\text { Sterility } \\
\text { of eggs } \\
\text { from }\end{array}$ \\
\cline { 3 - 4 } & $\begin{array}{c}\text { Apho- } \\
\text { late } \\
\text { colony } \\
(\%)\end{array}$ & $\begin{array}{c}\text { Reg- } \\
\text { ular } \\
\text { colony } \\
(\%)\end{array}$ & $\begin{array}{c}\text { regular } \\
\text { colony } \\
(\%)\end{array}$ \\
\hline
\end{tabular}

\begin{tabular}{|c|c|c|c|c|}
\hline \multicolumn{5}{|c|}{ Experiment 1} \\
\hline Parent & 5 & 96 & & 2 \\
\hline 1 & 5 & 89 & & 20 \\
\hline 2 & 5 & 75 & & 48 \\
\hline 3 & 5 & 59 & & 3 \\
\hline 4 & 5 & 46 & & 6 \\
\hline 5 & 15 & 72 & & 2 \\
\hline \multicolumn{5}{|c|}{ Experiment 2} \\
\hline Parent & 5 & 91 & & 6 \\
\hline 1 & 5 & 85 & & 1 \\
\hline 2 & 5 & 90 & & $\mathbf{0}$ \\
\hline 3 & 5 & 82 & & 1 \\
\hline 4 & 5 & 85 & & 2 \\
\hline 5 & 5 & 77 & & 19 \\
\hline 6 & 5 & 38 & & 15 \\
\hline 7 & 5 & 52 & 84 & 8 \\
\hline 8 & 5 & 50 & 93 & 17 \\
\hline 9 & 10 & 81 & 100 & 4 \\
\hline 10 & 10 & 88 & 100 & 18 \\
\hline 11 & 10 & 59 & 100 & 4 \\
\hline
\end{tabular}

31 JULY 1964 were used to produce the next generation of the colony. In addition, the percentage hatch of eggs laid in each generation was determined separately. In the first experiment females were individually confined for oviposition, and the percentage hatch was calculated for all eggs laid. In each generation 1000 to 5000 eggs were checked for sterility. In the second experiment a sample of about 200 eggs, taken at random from eggs laid by all females about 1 week after deposition, was used to determine percentage hatch. A complete cycle from third instar to third instar required about 3 weeks.

In the second experiment, beginning with the $F_{7}$ generation of the apholatetreated colony, larvae from the regular colony were treated with the same dosage of apholate as those in the experimental colony. This procedure provided a direct comparison between the sterility induced in the selected and in the unselected colonies. The percentage sterility in eggs from untreated mosquitoes from the regular colony was also determined in each generation (Table 1).

In the first experiment sterility of eggs from females exposed to $5 \mathrm{ppm}$ of apholate gradually declined from 96 percent in the parent generation to 46 percent in the $F_{4}$ generation. Larvae from the $F_{5}$ generation were exposed to $15 \mathrm{ppm}$, a dosage which usually causes complete or almost complete sterility. Resulting sterility of eggs from the females was 72 percent or 24 percent less than that obtained with the initial selection dosage of 5 ppm. The percentage sterility in the control colony ranged from 2 percent to 48 percent (average 13.5 percent); however, in 4 out of the 6 hatchings sterility was 6 percent or less.

In the second experiment, sterility ranged from 77 percent to 91 percent for the parent and first five generations, but decreased in the next three generations ( 38 percent to 52 percent). In the $F_{9}$ generation the selection concentration was increased to $10 \mathrm{ppm}$. This concentration caused 81 percent and 88 percent sterility in the next two generations, but in the $F_{11}$ generation sterility dropped to 59 percent. At this selection concentration, complete sterility was obtained with treated mosquitoes from the regular colony. In addition, these females produced far fewer eggs than females from the apholate colony. Sterility among untreated control females ranged from 0 percent to 19 percent.
These data indicate that $A$. aegypti can develop resistance to apholate. The degree of resistance encountered to date is not great, probably between four and five times that of the normal strain.

E. I. Hazard, C. S. Lofgren D. B. WOODARD*, H. R. Ford $\dagger$ B. M. GlanceY

Agricultural Research Service, U.S. Department of Agriculture, Gainesville, Florida

\section{References and Notes}

1. The chemical name of apholate is $2,2,4,4,6,6$ hexahydro - $2,2,4,4,6,6$ - hexakis - ( 1 - aziridinyl) 1,3,5,2,4,6-triazatriphosphorine.

2. D. E. Weidhaas, H. R. Ford, J. B. Gahan, C. N. Smith, New Jersey Mosquito Extermination Assoc. Proc. 48, 106 (1961)

3. D. E. Weidhaas, Nature 195, 786 (1962).

4. Supported in part by funds transferred from the U.S. Army Medical Research and Development Command, Office of the Surgeon General.

* Present address: U.S. Agricultural Research Service, Lake Charles, Louisiana.

Present address: c/o American Consulate, AID-4, ARS, Salisbury, Southern Rhodesia.

16 June 1964 